\title{
Several Shoot Of Cassava Plants
}

\author{
Ananto \\ Program Studi Agroteknologi Sekolah Tinggi Ilmu Pertanian (Stiper) Sawahlunto Sijunjung
}

\begin{abstract}
Research on Various Connections of Manihot esculenta crant for the purpose of obtaining good quality cassava seeds and increasing farmers' income, especially cassava farmers. This study was compiled based on a complete randomized design (CRD) with four treatment levels and three replications of each replication consisting of four treatments, consisting of control (A), connecting local cinnamon yams with yellow cassava $(B)$, connecting local cinnamon yams with plain cassava $(C)$, connecting local sweet potatoes with elephant cassava $(D)$. The variables observed were weight of fresh tuber weight $(\mathrm{kg})$, number of tubers (fruit), longest tuber length $(\mathrm{cm})$. Splicing using local cassava rootstock with elephant cassava stem (D), gives a better influence on fresh tuber weight (6.89 kg), tuber number (20.67 pieces) and longest tuber length $(63.55 \mathrm{~cm})$.
\end{abstract}

Key words: Cassava, shoots, Varieties

\section{PENDAHULUAN}

Ubi kayu (Manihot esculenta crant) merupakan salah satu bahan pangan yang utama. Di Indonesia ubi kayu merupakan makanan pokok ke tiga setelah padi dan jagung. Sedangkan untuk konsumsi penduduk dunia, khususnya penduduk negaranegara tropis, tiap tahun diproduksi sekitar 300 juta ton ubi kayu. (Rukmana, 1997. dalam Chalil, 2002).

Permintaan akan ubi kayu juga akan terus meningkat, seiring dengan banyaknya industri olahan ubi kayu yang berkembang pada saat ini, baik berupa industri kecil, industri menengah dan industri besar yang menggunakan bahan baku utamanya ubi kayu. Selain hal tersebut, pada tahun 2012 pemerintah Kabupaten Sijunjung telah menggalakkan penanaman ubi kayu guna untuk menambah pendapatan masyarakat dan memanfaatkan lahan yang dimiliki oleh semua lapisan masyarakat baik berupa lahan tidur yang masih belum digarap, maupun lahan sekitar pekarangan rumah yang masih kosong. Melalui program tersebut pemerintah daerah mengharapkan dukungan setiap unsur lapisan masyarakat dan para penyuluh pertanian.

Pada saat sekarang ini produksi ubi kayu terus mengalami penurunan, hal tersebut disebabkan oleh para petani kurang meminati tanaman ubi kayu ini karena tanaman ubi kayu bukan komoditas unggulan di Sijunjung khususnya dan sistim budidaya tanaman ubi kayu ini tidak mendapat perhatian khusus oleh instansi pertanian, selain hal tersebut, para petani membudidayakan tanaman ubi kayu menggunakan sistim budidaya tradisional.

Atman Roja (2009) menyatakan, bahwa khusus untuk ubi kayu, perananya dalam perekonomian nasional terus menurun karena dianggap bukan komoditas prioritas 
sehingga kurang mendapat dukungan investasi baik dari sisi penelitian dan pengembangan, penyuluhan, pengadaan sarana dan prasarana, serta dalam pengaturan dan pelayanan. Akibatnya luas areal panen terus berkurang dan produktivitas tidak meningkat secara nyata.

Salah satu penyebabnya adalah belum tepatnya teknologi untuk meningkatkan pendapatan petani ubi kayu, hal itu disebabkan karena sumberdaya manusia belum dimanfaatkan secara maksimal dalam pengelolaan usaha tani ubi kayu baik di lahan kering maupun lahan sawah, sehingga produktivitas hasil pertanian masih sangat beragam. Selain itu juga disebabkan oleh kemampuan masyarakat yang masih beragam dalam menyesuaikan pola yang sudah dimiliki dengan sumberdaya lahan yang tersedia di Propinsi Sumatera Barat. (Data BPS Sumatera Barat, 2007).

Walaupun menurut Chlil, D. (2003), teknologi budidaya yang digunakan sudah dapat dikatakan baik, tetapi dasar yang digunakan kemungkinan adalah teknologi sederhana yang telah digunakan selama bertahun-tahun dan memberikan hasil yang mencukupi. Akan tetapi dengan kondisi ubi kayu yang menggunakan zat hara yang relatif banyak maka sebenarnya diperlukan pengembangan teknologi budidaya untuk mempertahankan produksi dan produktivitas nya di masa mendatang. Dalam hal ini diperlukan perhatian dari pihak peneliti dan petugas lapangan seperti PPL untuk juga memperhatikan pengembangan teknologi ubi kayu. Karena selama ini jika perhatian peneliti dan petugas lapangan dapat dikatakan hanya terfokus pada dengan pengembangan budidaya tanaman padi.

Dengan terus menurunya produksi tanaman ubi kayu maka perlu pembenahan, misalnya dengan teknik perbanyakan benih tanaman ubi kayu diantaranya dengan mengguakan biji yang bermutu baik dan perbanyakan sambungan (okulasi), antara batang bawah jenis ubi kayu unggul dengan batang atas jenis ubi kayu biasa/karet. Hal ini sulit dikerjakan oleh petani dan membutuhkan tenaga yang professional.

Sambung pucuk merupakan salah satu alternatif yang dapat kita ambil selain dua hal diatas, Selain dapat meningkatkan hasil tanaman ubi kayu dan bisa dilakukan oleh parapetani pembudidaya tanaman ubi kayu tampa memerlukan tenaga ahli.

Kegiatan sambung pucuk kerap digunakan dengan menggabungkan batang bawah dan batang atas. Batang bawah diharapkan menjadi batang yang tahan terhadap patogen tanah dan kokoh sedangkan batang atas merupakan bagian yang memilki karakter produksi yang diinginkan. Batang bawah biasanya dipakai dari tanaman yang tumbuh dari biji sehingga perakarannya lebih kuat. Akan tetapi, batang bawah yang berasal dari biji memiliki karakter yang berbeda (segregasi). Teknologi perbanyakan mengusahakan batang bawah juga diperoleh seragam dari hasil stek. (hansdw08. student. ipb. 2011).

Penyambungan pada tanaman ubi kayu merupakan salah satu teknik yang dapat meningkatkan hasil pada budidaya tanaman ubi kayu khususnya, tanpa harus menambah luas lahan tanaman ubi kayu yang ada sehingga dapat meningkatkan pendapatan petani pembudidaya ubi kayu.

Tujuan dari penelitian ini adalah untuk mendapatkan bibit dan hasil ubikayu yang bermutu baik, 
dengan umur panen yang relatif pendek.

\section{BAHAN DAN METODE}

Penelitian ini telah dilakukan dengan menggunakan Rancangan Acak Lengkap (RAL) dengan 4 taraf perlakuan dan 3 ulangan. Seluruh data hasil pengamatan dianalisis dengan menggunakan analisis sidik ragam dengan perlakuan yang akan diberikan adalah :
A. Ubi kayu Varietas Manis lokal (control)

B. Ubi kayu Varietas Manis lokal Disambung dengan Adira 1 "Ubi kayu Kuning"

C. Ubi kayu Varietas Manis lokal Disambung dengan Adira 4 "Ubi kayu Putih"

D. Ubi kayu Varietas Manis lokal Disambung dengan Ubi Gajah.

\section{HASIL DAN PEMBAHASAN}

\subsection{Bobot Umbi Segar (kg)}

Tabel 1. Rata-rata hasil pengamatan bobot umbi segar dengan berbagai penyambungan pucuk pada tanaman ubi kayu pada umur 6 bulan.

\begin{tabular}{lccc}
\multicolumn{1}{c}{ Perlakuan } & Rata - rata (kg) \\
\hline Ubi kayu varietas manis lokal dengan & 6,89 & a \\
Ubi gajah (D) & 4,59 & b \\
$\begin{array}{l}\text { Ubi kayu varietas manis lokal dengan } \\
\text { ubi kayu Biasa (C) }\end{array}$ & 4,56 & b \\
$\begin{array}{l}\text { Tampa penyambungan/kontrol (A) } \\
\text { Ubi kayu varietas manis lokal dengan } \\
\text { ubi kayu kuning (B) }\end{array}$ & 3,23 & $\mathrm{c}$ \\
\hline
\end{tabular}

$\mathrm{KK}=16,20$

Angka-angka yang diikuti oleh huruf kecil yang sama berbeda tidak nyata menurut DNMRT pada taraf nyata $5 \%$

Dari tabel di atas bahwa bobot umbi segar tanaman dengan penyambungan pucuk pada tanaman ubi kayu menunjukan hasil berbeda nyata, dari hasil penelitian ini bobot umbi teringgi terdapat pada perlakuan D yakni $6,89 \mathrm{~kg}$ tanaman ubi kayu manis lokal batang bawah disambung dengan ubi gajah batang atas, hal tersebut diduga karena tanaman ubi gajah memiliki percabangan dan daun-daun yang yang banyak dari varietas lain, sehingga hasil fotosintesis berjalan lebih baik sehingga cadangan makanan yang dihasilkan dalam bentuk karbohidrat yang tersimpan dalam bentuk umbi akan lebih banyak pula.

\subsection{Jumlah Umbi (buah)}

Tabel 2. Rata- rata hasil pengamatan jumlah umbi dengan berbagai penyambungan pucuk pada tanaman ubi kayu pada umur 6 bulan.

\begin{tabular}{lr}
\hline \multicolumn{1}{c}{ Perlakuan } & Rata - rata (b \\
\hline $\begin{array}{l}\text { Ubi kayu varietas manis lokal dengan } \\
\text { ubi gajah (D) }\end{array}$ & $20,67 \quad$ a
\end{tabular}


Tampa penyambungan/kontrol (A)

Ubi kayu varietas manis lokal dengan

ubi kayu Biasa (C)

$16,67 \quad b$

Ubi kayu varietas manis lokal dengan

ubi kayu kuning (B)

$13,56 \quad \mathrm{c}$

$\mathrm{KK}=10,07$

Angka-angka yang diikuti oleh huruf kecil yang sama berbeda tidak nyata menurut DNMRT pada taraf nyata $5 \%$

Pada Tabel 2 dapat dilihat bahwa jumlah umbi terbanyak terdapat pada perlakuan D yaitu 20,67 buah, penyambungan batang bawah ubi kayu varietas manis lokal dengan penyambungan batang atas mengunakan ubi gajah. Hal tersebut diduga karena tanaman ubi gajah ini sangat kuat dalam mengambil hara yang terkandung dalam tanah, baik bentuk hara yang dibutuhkan oleh tanaman dalam jumlah banyak (hara makro) maupun hara yang sedikit dibutuhkan tanaman tersebut (hara mikro) sehingga mendorong terjadinya pembelahan sel-sel kemudian membentuk umbi/akar (faktor ganetik tanaman) media tanam juga sangat berpengaruh terhadap panjangnya umbi/akar seperti kondisi tanah, semakin gembur tanah pada media tanam maka kemungkinan perpanjangan akar akan lebih panjang..

\subsection{Panjang Umbi Terpanjang (cm)}

Tabel 3 Rata- rata hasil pengamatan panjang umbi terpanjang dengan berbagai penyambungan pucuk pada tanaman ubi kayu pada umur 6 bulan.

\begin{tabular}{lccc}
\multicolumn{1}{c}{ Perlakuan } & Rata - rata $(\mathrm{cm})$ \\
\hline $\begin{array}{l}\text { Ubi kayu varietas manis lokal dengan } \\
\text { ubi gajah (D) }\end{array}$ & 63,55 a & \\
$\begin{array}{l}\text { Ubi kayu varietas manis lokal dengan } \\
\text { ubi kayu kuning (B) }\end{array}$ & 46,00 & b & \\
$\begin{array}{l}\text { Ubi kayu varietas manis lokal dengan } \\
\text { ubi kayu Biasa (C) }\end{array}$ & 43,89 & b \\
Tampa penyambungan/kontrol (A) & 39,89 & $\mathrm{c}$ \\
\hline KK = 6,87 & & & \\
\hline
\end{tabular}

Angka-angka yang diikuti oleh huruf kecil yang sama berbeda tidak nyata menurut DNMRT pada taraf nyata $5 \%$

Pada Tabel 3 dapat dilihat bahwa pembentukan panjang umbi terpanjang terdapat pada perlakuan D $63,55 \mathrm{~cm}$. hal ini diduga karena ubi gajah ini mempunyai sifat yang sangat rakus terhadap penyerapan hara dan air yang terkandung dalam tanah, dengan banyaknya hara dan air yang diserap tanaman ubi gajah ini maka hormon-hormon yang dihasilkan akan lebih banyak terutama hormon auksin yang berfungsi untuk pembelahan sel-sel pada akar akan lebih cepat berfunsi dan akar/umbi yang tercipta akan lebih panjang. 


\section{KESIMPULAN}

Penyambungan batang bawah menggunakan varietas ubi kayu manis lokal dengan penyambungan batang atas menggunakan varietas ubi gajah (D) memberikan pengaruh lebih baik terhadap bobot umbi segar rata-rata per tanaman sampel 6,89 kg, jumlah umbi terbanyak rata-rata pertanaman sampel 20,67 buah dan panjang umbi terpanjang rata-rata pertanaman sampel $63,55 \mathrm{~cm}$.

\section{DAFTAR PUSTAKA}

BPS Sumatera Barat. 2007. Sumatera Barat Dalam Angka 2006/2007. 607 hlm. Padang.

Chalil, D. 2003. Agribisnis Ubikayu di Sumatra Utara. Jurusan Sosial Ekonomi Pertanian, Fakultas Pertanian. Skripsi Universitas Sumatra Utara. Medan.

Fadli, A. A 2005. Pertumbuhan Embrio Biji Mangga Marapalam (mangifera inndica) secara in fitro pada Beberapa Media Basal. Fakultas Pertanian Universitas Andalas Padang. Padang.

Hansdw08. student. ipb. ac. id / tag / 22 februari 2011 / Sambung
Pucuk / 24 November 2011 jam 11.00 wib.

Heddy, S. 1987. Biologi Pertanian, Tinjauan Singkat Tentang Agronimi, Fisiologi, Sistematika Dan Genetika Dasar Tumbuh-tumbuhan. Rajawali Pers. Jakarta.

Http: //neocassava. blogspot. com / 2007. 05 / I html. Budidaya Ubikayu. 24 November 2011 jam 10.wib.

Http: //bp4kkabsukabumi. net. Budidaya Ubikayu. 24 November 2011 jam 10.30 wib.

Http: //books. google. com/Sejarah Penyebaran Tanaman Singkong/ 18 Desember 2011 jam 19.00 Wib.

Http://manycalories.com/id/kandung an Gizi dalam Ubikayu/ 12 September 2012 jam 13.45 Wib.

Http://id. scribd. com/doc/80768987/Singkong -Gajah-Primadona. 18 Oktober 2012 jam 19.30 Wib

Http// puslittan. bogor. net/ Deskripsi Tanaman Ubikayu (cassava) 18 Oktober 2012 jam 19.45 Wib. 